\title{
ANNUAL INCIDENCE OF CONGENITAL HYPOTHYROIDISM IN SULAIMANI CITY-KURDISTAN REGION/IRAQ
}

\author{
ADNAN MOHAMMED HASAN, MBChB, CABP * \\ HEERSH HMH RAOF SAEED, MBChB, FIBMS ** \\ BAKIR RAHIM RASHID, MBChB, FIBMS ** \\ PISHDAR ABDULLA, MBChB, FKBMS ***
}

\section{Submitted 14/1/2017; accepted 31/12/2017}

\begin{abstract}
Background: Congenital hypothyroidism is one of the most common preventable causes of intellectual disability. Most neonates born with congenital hypothyroidism are normal on clinical examination. Hypothyroidism in the newborn period is almost always overlooked, and as a result delay in management will cause profound neurological insult and mental retardation. Neonatal screening in Sulaimani city (center of Sulaimani governorate in north of Iraq) had started in 2013 for screening of Phenylketonuria, congenital hypothyroidism and glucose 6 phosphatase deficiency.

Subject and Method: All neonates born in Sulaimani city including all hospital deliveries (both private and public governmental hospitals) in addition to the home deliveries that were referred to (Registration Bureau of Births and Deaths) during the period from January 1st to December 31st 2014 were included. Thyroid stimulating hormone was measured from heel prick blood samples obtained from neonates aged between 3 and 10 days. Neonates showing a TSH level of $\geq 5 \mathrm{mIU} / \mathrm{L}$ were recalled to Sulaimani pediatric teaching hospital for confirmation of diagnosis. Aim of our study was to determine annual incidence of congenital hypothyroidism in the city.

Results: Among 13050 neonates screened for congenital hypothyroidism, $75(0.5 \%)$ were recalled $(\mathrm{TSH}, \geq 5 \mathrm{mIU} / \mathrm{L})$. Congenital hypothyroidism was detected in $11(14.6 \%)$ recalled neonates (incidence of congenital hypothyroidism in our study 1 in 1186 live births).

Conclusions: According to this result, we concluded that Sulaimani city have high incidence of congenital hypothyroidism and in future, all newborn should be screened in this region including district areas.
\end{abstract}

Duhok Med J 2017; 11 (2): 27-36.

Keywords: Congenital Hypothyroidism; Sulaimani city; Newborn screening programs.

$\mathrm{T}$ hyroid hormone has a key role for normal development of the nervous system $^{1}$. Since fetal life till 2 years after birth is deemed as a critical period for central nervous system which depends on thyroid hormone for its development ${ }^{2}$. Congenital hypothyroidism $(\mathrm{CH})$ is the result of hypothalamus-pituitary-thyroid axis dysfunction, which leads to reduction of thyroxin secretion, and consequently causes severe insult to the brain. Congenital hypothyroidism is categorized as either permanent or transient $\mathrm{CH}$ (PCH/TCH), 2 main etiologies suggested for $\mathrm{PCH}$, the first one $(85 \%)$ is linked to dysgenesis, including atrophy, athyreosis, and ectopic, and the second one (15\%) has hereditary basis (major cause is inborn errors of thyroid hormone( $\mathrm{TH})$ synthesis), nevertheless the TCH is unknown. According to related investigations, TCH is resulted from a set of factors including; multiplicity (triple and quadruple), prematurity, low birth weight, and iodine

\footnotetext{
* Professor, Department of Pediatrics, School of Medicine, University of Sulaimani, Sulaimani, Kurdistan Region, Iraq.

** Lecturer, Department of Pediatrics, School of Medicine, University of Sulaimani, Sulaimani, Kurdistan Region, Iraq.

*** Senior House Officer, Sulaimani Pediatric Teaching Hospital, Sulaimani, Kurdistan Region, Iraq.

Correspondence author to: Heersh Hmh Raof Saeed, heersh.raof@univsul.edu.iq, Mobil +9647702272550
} 


\section{ANNUAL INCIDENCE OF CONGENITAL HYPOTHYROIDISM IN SULAIMANI}

deficiency or excessive use of antithyroid drugs. As well as, TCH may also be affected by interaction between genes and the environmental factors ${ }^{3,4,5,6}$.

Central hypothyroidism - screening programs that utilize the initial T4-blood level and follow-up TSH approach are introduced for diagnosis of Infants with central (hypothalamic or pituitary) hypothyroidism. Central hypothyroidism occurs in $1: 25,000$ to $1: 100,000$ newborns ${ }^{7}$.

The high percentage (more than $95 \%$ ) of infants with $\mathrm{CH}$ do not show clinical manifestations of hypothyroidism at birth ${ }^{8}$. Birth length and weight typically are within the normal range although birth weight can be increased, head circumference also may be increased. Absence of knee epiphyses are more likely to take place among males in comparison with the females (40 versus 28 percent, respectively) $)^{9,10}$.

Lethargy, slow movement, hoarse cry, feeding problems, constipation, macroglossia, umbilical hernia, large fontanels, hypotonia, dry skin, hypothermia, and prolonged jaundice may be considered as early symptoms and signs of $\mathrm{CH}^{11}$.

An inverse relationship between age of diagnosis and future intelligence quotient (IQ) is observed, so that the delay in diagnosis of $\mathrm{CH}$ leads to lower IQ in future $^{12}$. Since there is no significant clinical manifestations of thyroid deficiency at birth and the majority of cases are sporadic, it is impossible to predict which infants are likely to be affected. Thus, newborn screening programs (NSP) which was developed in the mid-1970s, is a process that either thyroxine (T4) or thyroprotein (TSH) are measured in heel-stick blood samples to detect this condition as soon as possible ${ }^{13}$. Before practicing of screening in 1970, one third of congenital hypothyroidism cases were not diagnosed until 3 months after birth when irreversible mental retardation had been developed ${ }^{13,14}$. By five or six months delay in management of $\mathrm{CH}$ cases, the IQ could be affected significantly in comparison with those who were detected at birth ${ }^{16}$.

Infants with abnormal screening results are recalled for further testing. At this session, the infants are examined and a blood specimens are obtained by venipuncture to support hypothyroidism detection. If the diagnosis of hypothyroidism is confirmed, other sophisticated investigations (such as thyroid radionuclide uptake and imaging, ultrasonography, tests for thyroid autoantibodies, serum thyroglobulin assay or urinary iodine excretion) may be performed to identify the final diagnosis.

Prematurity is suggested as another cause for low serum total and free $\mathrm{T} 4$ and normal serum TSH concentration ${ }^{17}$.

As the main purpose of treatment; a normal growth and development and similar psychometric outcome to genetic potential should be obtained by normalizing the serum $\mathrm{T} 4$ concentration rapidly followed by continuous clinical and biochemical euthyroidism. Oral levothyroxine (L-T4) is the treatment of $\mathrm{CH}$ cases. Dose of L-T4 - Both dose of $\mathrm{TH}$ replacement and timing are important $^{18,19,20}$. The American Academy of Pediatrics (AAP) recommends a starting L-T4 dose of 10 to $15 \mathrm{mcg} / \mathrm{kg} / \mathrm{day}^{21}$. The initial aim of management should be to restore the serum $\mathrm{T} 4$ concentration to more 
than $10 \mathrm{mcg} / \mathrm{dL}(>129 \mathrm{nmol} / \mathrm{L})$ or a serum free $\mathrm{T} 4$ in the upper half of the normal range for age as soon as possible, and keep the serum $\mathrm{T} 4$ or free $\mathrm{T} 4$ (fT4) concentration in the upper half of the normal range in the first year of life.

In the past 40 years, neonatal screening programs for $\mathrm{CH}$ decreased incidences of severe MR in those infants who were diagnosed and treated early in infancy. The neuropsychological evaluation of children with $\mathrm{CH}$ detected early has shown normal mental development in almost all cases, although, a certain percentage of infants albeit treated early, show mild anomalies of mental development.

The aim of this study was to find out the incidence of congenital $\mathrm{CH}$ in Sulaimaniya city.

\section{PATIENTS AND METHODS}

We did a retrospective study in Sulaimani Pediatric Teaching Hospital which started neonatal screening for all life births inside Sulaiamni city (which is center of Sulaimani Governorate) in June2013. From the total of 32055 neonates who were born inside Sulaimani Governorate and referred to (Chwarbakh Bureau for Births and Deaths) in Chwarbakh Street, $40.7 \%$ of newborns (13050 neonate) were from Sulaimani city and included in this study which extended from January

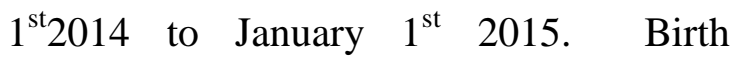
certificate are only issued from this Bureau after the completion of screening tests, so one can be certain that almost all newborn babies during this period were included in the study except for small number of children who were discussed latter in exclusion criteria . Demographic information, including data for age, weight, sex, maturity, parental consanguinity were recorded in a questionnaire. Thyroid stimulating hormone concentrations were measured from blood sample taken from heel-prick by trained nurses for all newborn aged between 3 and10 days (all children included and no family registerd to refuse this test. Thespecimen were subjected to enzyme linked immunosorbent assay (ELISA).

Babies were not included in the screening program:

- Refugee babies from other provinces of the country, Syrians and Iranians.

-Sick babies who remain in hospital the first 2 weeks of life.

-Babies from districts and towns outside of Sulaimani city (target group was babies from Sulaimani city).

At registration bureau Blood specimen were collected on a collection card (we used Whatman903 to collect the infant's blood on the pre-printed circles on the sample card) and all collected sample for that day were transferred to screening department in pediatric teaching hospital in a special container. In hospital using Neo-PKU Kit: Quantitative enzymatic assay of TSH in dried blood spots were performed. Blood TSH level of $5 \mathrm{mIU} / \mathrm{L}$ is considered as the cutoff point. Neonates with TSH levels of less than $5 \mathrm{mIU} / \mathrm{L}$ were excluded from further evaluation. However, neonates with TSH levels greater than $5 \mathrm{mIU} / \mathrm{L}$ in filter-paper blood samples were recalled within 1 week for confirmation of $\mathrm{CH}$ by radioimmunoassay for TSH and T4 levels from venous serum samples. 
Primary $\mathrm{CH}$ was diagnosed if $\mathrm{T} 4$ levels were less than $111.11 \mathrm{nmol} / \mathrm{L}$ and $\mathrm{TSH}$ levels were more than $10 \mathrm{mIU} / \mathrm{L}$.

\section{RESULTS}

A Total of 013050 newborns who were included in our study, 6690 were male $(51.26 \%)$ and 6360 were female $(48.74 \%)$, which mean male: female ratio of (1.1:1). Thyroid stimulating hormone value of $5 \mathrm{mIU} / \mathrm{L}$ was considered as cut value for recall for further investigation in hospital, From all screened newborn $75(0.5 \%)$ of them have a TSH of $>5 \mathrm{mIU} / 1$, of which 42 were females, and 33 males giving a female to male ratio of 1.3:1.

Distribution of the TSH level in these 75 cases were as follows:

64 cases $(85.33 \%)$ from $5-10 \mathrm{mIU} / \mathrm{L}$

4 cases $(5.33 \%)$ from $10.1-20 \mathrm{mIU} / \mathrm{L}$

2 cases $(2.66 \%)$ from $20.1-60 \mathrm{mIU} / \mathrm{L}$

5 cases $(6.66 \%)$ more than $60 \mathrm{mIU} / \mathrm{L}$

Only 70 patients recalled (5 cases were lost because of not responding after recalling, their TSH level were between 5$10 \mathrm{mIU} / \mathrm{L}$ ). Second heel prick blood sample results revealed that only 11 patients had TSH level more than 10mul/l and diagnosed as $\mathrm{CH}$, of which 6 were females, and 5 males giving a female to male ratio of 1.2:1.

Distribution of the TSH level in these 11 cases were as follows:

2 cases $(18.18 \%)$ from $10-15 \mathrm{mIU} / \mathrm{L}$ 3 cases $(27.27 \%)$ from 15.1-20 mIU/L 1 case $(9 \%)$ from $20.1-60 \mathrm{mIU} / \mathrm{L}$ 5 cases $(45.45 \%)$ more than $60 \mathrm{mIU} / \mathrm{L}$

Regarding parents of cases which were diagnosed as a case of $\mathrm{CH}$ : three of them had consanguinity positive, no one had history of drug use during pregnancy or exposure to radiation.
One premature and ten full term, one had family history of $\mathrm{CH}$, the annual incidence of $\mathrm{CH}$ in our study was 1 in 1186 .

\section{DISCUSSION}

The annual incidence of $\mathrm{CH}$ among neonates in Sulaimania city has not been determined in past, but this study shows that the estimated incidence is 1 in 1186 live births which is considered high incidence region compared to other countries as the incidence of $\mathrm{CH}$ varies throughout the world, but the worldwide reported incidence is 1 in 3000-4000 live births $^{22,23}$. It has been reported to be 1:2097 in Saudi Arabia ${ }^{24}$ and another study which was performed in between 1997 and 2001 in Tehran and Damavand by Ordookhani, et al. ${ }^{25}$ showed an incidence of 1:914, although it was reported to be $1: 1433$ in the study of Amirhakimi et al from Shiraz in $1990^{26}$, and another study showed incidence of 1:370 which was done by Hashemipour et al from Isfahan ${ }^{27}$. We think that similarity in incidence of $\mathrm{CH}$ between our city and Iranian province is a result of similar consanguinity marriage rate in the community and screening kits used were manufactured by the same country.

In Baghdad, a study which was performed from Dec. $1^{\text {st }} 2001$ to Dec. $31^{\text {st }} .2002$ on a total of 6949 neonates were screened for $\mathrm{CH}$, three neonates were proved to have Congenital hypothyroidism (incidence of 1: 2275$)^{28}$.

The $\mathrm{CH}$ re-call rates also vary from $0.16 \%$ to $3.3 \%$ among different countries in which the screening programs were performed between 3 and 5 days after birth $^{29,30,31}$. In the present study, the recall rate was $0.57 \%$, the recall rates in other 
countries, after primary TSH level assessment in neonates aged 3-5 days, varied from $0.16 \%$ to $3.3 \%$. The recall rates were $0.16 \%$ in the Philippines, $0.3 \%$ in Greece, $2.3 \%$ in Turkey, $0.35 \%$ in Austria, $0.28-0.29 \%$ in Hungary, and 3.3\% in Estonia ${ }^{24,30,32-37}$. In contrast, in some studies conducted in Italy, the recall rate measured on the basis of $\mathrm{T} 4$ levels was $2.5 \%$, while that measured on the basis of both T4 and TSH levels was $0.11 \%^{38}$, these huge differences in recall rate for newborn screened for congenital hypothyroidism mainly depends on either T4 level or both T4 and TSH measurement done for screening and also depend on time of taking blood sample as in studies in which most of samples are taken during $3^{\text {rd }}$ and $4^{\text {th }}$ days of life will have a high recall rate because of larger number of newborns with transient hypothyroidism will be recalled. In addition the cutoff point for recall is detrimental, the lower the cutoff point of TSH level; the higher the recall rate.

The female: male ratio for $\mathrm{CH}$ varies in different countries and is reported as 6:1 in Estonia, 3:1 in Saudi Arabia, 1.2:1 in Japan and as $1.4: 1$ in the eastern part of $\operatorname{Iran}^{39,40,41,42}$. Results of most screening programs also suggest a female preponderance for $\mathrm{CH}$, approaching a 2:1 female to male ratio ${ }^{43}$. In our study female to male ratio was $1.2: 1$. The differences in prevalence and in female/male ratios may be due to differences in prevalence of consanguineous marriages and to differences in frequency of undiagnosed family history of $\mathrm{CH}$, as reported also by Castanet et $\mathrm{al}^{43}$. Again, the preponderance of $\mathrm{CH}$ in females might be due to undiscovered genetic factors, perhaps linked to autoimmuity, which is usually more common in females ${ }^{44}$.

Several studies have shown that $\mathrm{CH}$ is more prevalent among Asians than among non-Asians. Rosenthal et al. performed a study on the prevalence of $\mathrm{CH}$ among different races, nationalities, and small communities, particularly Muslims and Asians, in the United Kingdom ${ }^{45}$. They found that the incidence rate of $\mathrm{CH}$ among Asians was 1 in 918 live births; our results were closer to this value than they were to the incidence of $\mathrm{CH}$ in non-Asians (1 in 3391 live births). They attributed this high prevalence of $\mathrm{CH}$ among Asians to increased rates of parental consanguinity ${ }^{43}$. In conclusion, the annual incidence of $\mathrm{CH}$ in the present study is similar to the incidence in the nearby countries. This study might be used as a Pilot for introducing a national neonatal screening program for $\mathrm{CH}$ in Iraq as it can be conducted in hospitals following an intensive training course for doctors, nurses and laboratory personnel.

\section{REFERENCES}

1. Bernal J. Action of thyroid hormone in brain. $\mathrm{J}$ Endocrinol Invest 2002;25(3):268-88

2. Zoeller Rt, Rouext J. Timing of thyroid hormone action in the developing brain: clinical observations and experimental findings. J Neuroendocrionol 2004;16(10):804-18.

3. Bhavani N. Transient congenital hypothyroidism. Indian J Endocrinol Metab. 2011;15:S117-S120.

4. Srinivasan R, Harigopal S, Turner S, Cheetham T. Permanent and transient congenital hypothyroidism in 
preterm infants. Acta Paediatr. 2012;101:e179-e182.

5. Zung A, Yehieli A, Almashanu S. Neonatal hyperthyrotropinemia is associated with low birth weight: a twin study. Eur J Endocrinol. 2013;168:263-269.

6. Yaman AK, Demirel F, Ermis B, Piskin IE. Maternal and neonatal urinary iodine status and its effect on neonatal TSH levels in a mildly iodine-deficient area. J Clin Res Pediatr Endocrinol. 2013;5:90-94.

7. Hanna CE, Krainz PL, Skeels MR, Miyahira RS, Sesser DE, LaFranchi SH. Detection of congenital hypopituitary hypothyroidism: tenyear experience in the Northwest Regional Screening Program. J Pediatr 1986; 109:959.

8. Alm J, Hagenfeldt L, Larsson A, Lundberg K. Incidence of Congenital Hypothyroidism: retrospective study of neonatal laboratory screening versus clinical symptoms as indicators leading to diagnosis. $\mathrm{Br}$ Med J (Clin Res Ed) 1984; 289:1171.

9. Law WY, Bradley DM, Lazarus JH, John R, Gregory JW. CH in Wales (1982-1993): demographic features, clinical presentation and effects on early neurodevelopment. Clin Endocrinol (Oxf) 1998; 48:201.

10. Van Vliet G, Larroque B, Bubuteishvili L, Supernant K, Leger J. Sex-specific impact of Congenital Hypothyroidism due to thyroid dysgenesis on skeletal maturation in term newborns. J Clin Endocrinol Metab 2003; 88:2009.

11. LaFranchi SH, Murphey WH, Foley TP Jr, Larsen PR, Buist NRM.
Neonatal hypothyroidism detected by the Northwest Regional Screening Program. Pediatrics 1979; 63:180.

12. Klein AH, Meltzer S, Kenny FM. Improved prognosis in Congenital Hypothyroidism treated before age three months. J Pediatr 1972; 81:912.

13. Dussault JH, Coulombe P, Laberge C, Letarte J, Guyda H, Khoury K. Preliminary report on a mass screening program for neonatal hypothyroidism. J Pediatr 1975; 86:670.

14. Dussault JH. The anecdotal history of screening for congenital hypothyroidism. J Clin Endocrinol Metab. 1999;84(12):4332-4. [PubMed]

16. Fisher DA, Dussault JH, Foley TP, $\mathrm{Jr}$, Klein AH, LaFranchi S, Larsen $\mathrm{PR}$, et al. Screening for congenital hypothyroidism: results of screening one million North American infants. J Pediatr. 1979;94(5):700-5. [PubMed]

17. Fisher DA, Schoen EJ, La Franchi S, Mandel SH, Nelson JC, Carlton EI, et al. The hypothalamic-pituitarythyroid negative feedback control axis in children with treated congenital hypothyroidism. J Clin Endocrinol Metab. 2000;85(8):27227. [PubMed]

18. Fisher DA. Euthyroid lowT4(T4) and T3 (T3) states in prematures and sick neonates. Pediatr Clin North Am 1990; 37:1297.

19. Selva KA, Harper A, Downs A, Blasco PA, Lafranchi SH. Neurodevelopmental outcomes in Congenital Hypothyroidism: comparison of initial $\mathrm{T} 4$ dose and 
time to reach target T4 and TSH. J

Pediatr 2005; 147:775.

20. LaFranchi SH, Austin J. How should we be treating children with Congenital Hypothyroidism? J Pediatr Endocrinol Metab 2007; 20:559.

21. Germak JA, Foley TP Jr. Longitudinal assessment of Lthyroxine therapy for Congenital Hypothyroidism. J Pediatr 1990; 117:211.

22. American Academy of Pediatrics, Rose SR, Section on Endocrinology and Committee on Genetics, American Thyroid Association. Update of newborn screening and therapy for Congenital Hypothyroidism. Pediatrics 2006; 117:2290.

23. Loeber JG. Neonatal screening in Europe; the situation in 2004. J Inherit Metab Dis 2007;30(4): 430-8.

24. Mengreli C, Yiannakou L, Pantelakis $\mathrm{S}$. The screening programme for congenital hypothyroidism in Greece: evidence of iodine deficiency in some areas of the country. Acta Paediatr Suppl. 1994;394:47-51.

25. Majeed-Saidan M.A., Joyce J., Khan M., Hamam H.D., Congenital hypothyroidism: the Riyadh Military Hospital experience, Clin. Endocrinol. 38 (1993) 191-195.

26. Ordookhani A, Mirmiran M, Hedayati M, Mirjalili F. An interim report of the pilot study of screening for congenital hypothyroidism in Tehran and Damavand using cord blood spot samples. Euro J Pediatr 2003;162(3):202-3.
27. Karamizadeh Z, Amirhakimi GH. Incidence of congenital hypothyroidism in Fars province, Iran. Iran J Med Sci 1992;17(12):78-80.

28. Hashemipour M, Amini M, Iranpour R, Dana MK, Amini M, Iran Pour $\mathrm{R}$, et al. Prevalence of congenital hypothyroidism in Isfahan, Iran: results of a survey on 20,000 neonates. Horm Res 2004;62(2):7983.

29. Ammash IS, Aldoree F, Al- Jumaily A, Sulaiman TI, Mahmood WT. J Fac Med Baghdad 2008, Vol. 50, No.4,page 416.

30. Fagela-Domingo C, Padilla CD, Cutiongco EM. Screening for congenital hypothyroidism among Philippine newborn infants. Philippine newborn screening study group. Southeast Asian J Trop Med Public Health 1999;30(Suppl 2):2022.

31. Simsek E, Karabay M, Kocabay K. Neonatal screening for congenital hypothyroidism in West Black Sea area, Turkey. Int $\mathbf{J}$ Clin Pract 2005;59:336-341.

32. Mikelsaar RV, Zordania R, Viikmaa M, Kudrjavtseva G. Neonatal screening for congenital hypothyroidism in Estonia. $\mathrm{J}$ Med Screen 1998;5:20-21.

35. Moslinger D, Frisch H, Strobl W, Stockler-Ipsiroglu S. Neonatal screening for congenital hypothyroidism. Acta Med Austriaca. 1997;24(4):162-4.

36. Peter F, Blatniczky L, Kovacs L, Tar A. Experience with neonatal screening for congenital 


\section{ANNUAL INCIDENCE OF CONGENITAL HYPOTHYROIDISM IN SULAIMANI}

hypothyroidism in Hungary.

Endocrinol Exp. 1989;23(2):143-51.

37. Yordam N, Calikoglu AS, Hatun S, Kandemir N, Oguz H, Tezic T, et al. Screening for congenital hypothyroidism in Turkey. Eur J Pediatr. 1995;154(8):614-6.

38. Berardi R, Baracchi MR, Borgogni P, Margollicci MA, Mattei R, Fois A. [Results of a screening project for congenital hypothyroidism in 4 years of experience]. Pediatr Med Chir. 1982;4(6):657-60.

39. Dilli D, Czbaş S, Acıcan D, Yamak N, Ertek M, Dilmen U. Establishment and development of a national newborn screening programme for congenital hypothyroidism in Turkey J Clin Res Pediatr Endocrinol 2013;5:73-79.

40. Olney RS, Grosse SD, Vogt RF Jr. Prevalence of congenital hypothyroidism-current trends and future directions: workshop summary. Pediatrics 2010;125(Suppl 2):31-36.

41. Al-Maghamsi MS, Al-Hawsawi ZM, Ghulam GN, Okasha AM. Screening for congenital hypothyroidism in north-west region of Saudi Arabia. Saudi Med J 2002;23:1518-1521.

42. Miyai K, Inaoka K, Miyagi T; Committee for Newborn and Infant Screening in Osaka (CONISO). Further studies on episodic occurrence of congenital dysgenetic hypothyroidism in Osaka, Japan. Endocr J 2005;52:599-603.

43. Castanet M, Polak M, Bonaiti-Pellie C, Lyonnet S, Czernichow P, Leger $\mathrm{J}$; AFDPHE (Association Francaise pour le Depistage et la Prevention des Handicaps de l'Enfant). Nineteen years of national screening for congenital hypothyroidism: familial cases with thyroid dysgenesis suggest the involvement of genetic factors. J Clin Endocrinol Metab 2001;86:2009-2014.

44. Rastogi M, Lafranchi S. Congenital hypothyroidism OJRD 2010;5:17-22.

45. Panamonta O, Tuksapun S, Kiatchoosakun P, Jirapradittha J, Kirdpon W, Loapaiboon M. Newborn screening for congenital hypothyroidism in Khon Kean university hospital. J Med Assoc Thai 2003;86(10):932-9. 


\section{توختة}

ريذةي سالانةي ئةو منالآنةي لة شاري سليماني لة دايك ئةبن وة توشى كةمي رذينى دةرةقى زطماكي بوون لـ دان

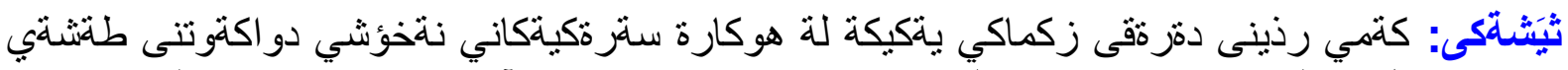

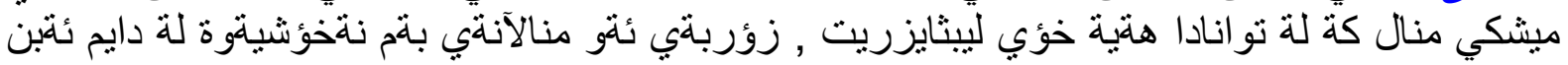

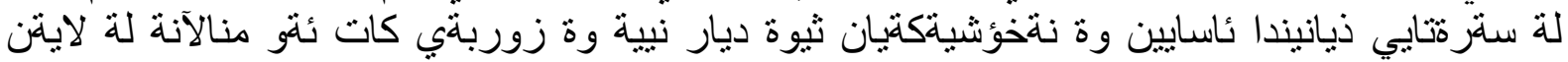

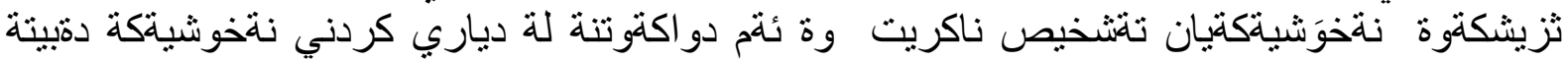

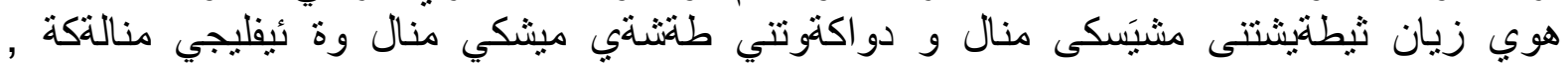

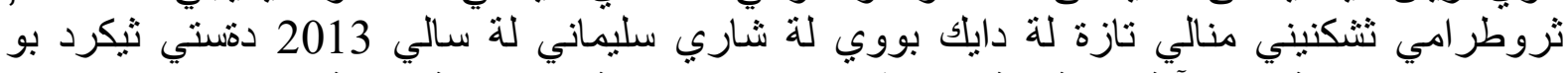

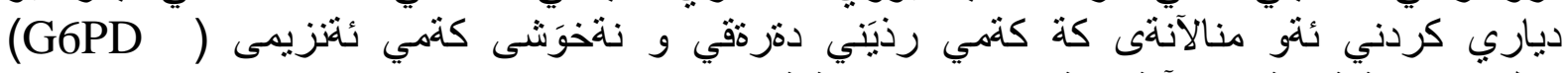

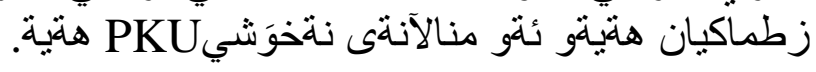

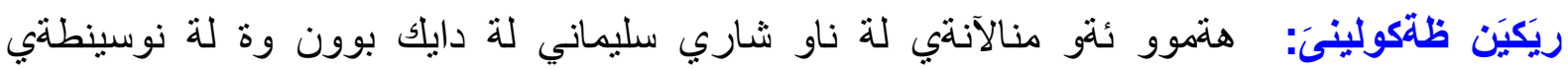

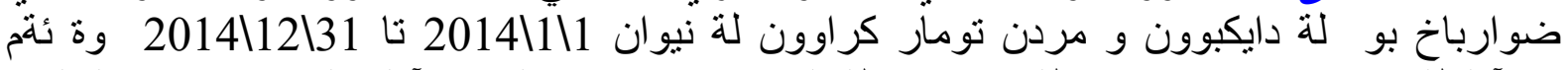

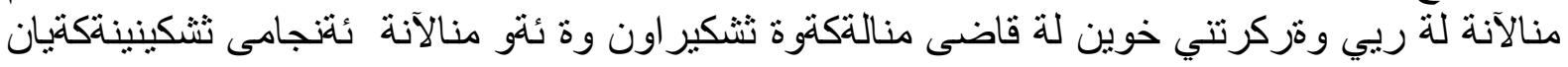

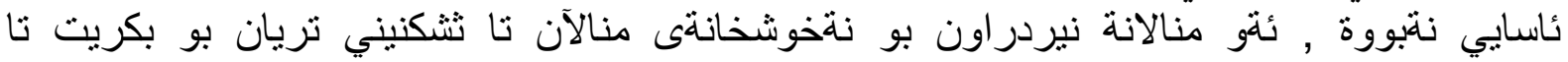
ناخخوشيةكة دياري بكريت.

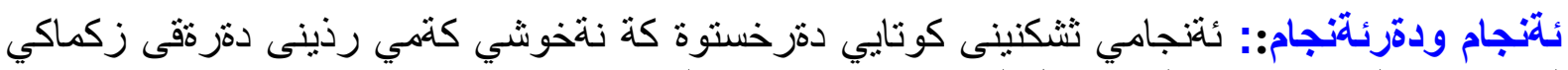

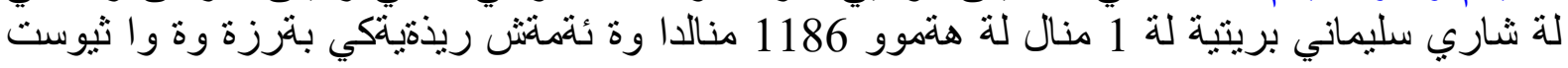

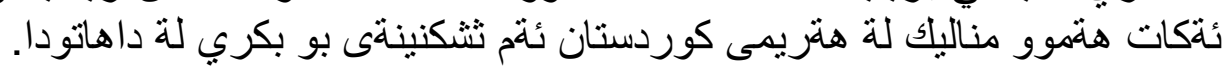




\section{الخلاصة}

المعدل السنوي لقصور الغدة الدرقية الخلقي في المدينة السليمانية

الخلفية والأهداف: قصور الغدة الدرقية الخلقي، هو واحد من أسباب الأكثر شيوعا للإعاقة الفكرية و الذي يمكن يمكن الوقاية منها. معظم الأطفال حديثي الولادة الذين عندهم هذه مرض يبدون طبيعين في الفحص السريري. قصور الغدة الدرقية في فترة الولادة يتم تجاهله غالبا ، و تأخير تشخيص يسبباعاقة العصبية دايمة والتخلف العقلي. وفحص الأطفال حديثي الولادة في مدينة السليمانية (مركز محافظة السليمانية في شمال العراق) بدأت في عام 2013 لفحص قصور الغدة الدرقية الخلقي ونقص انزيم G6PD و مرض GKU

طرق البحث: شملت جميع حديثي الولادة ولا في مدينة السليمانية بما في ذلك جميع الولادات في المستشفى (كل من المستشفيات الحكومية العامة والخاصة) بالإضافة إلى الولادات المنزلية التي تم تسجيلهم في (مكتب تسجيل ولادات والوفيات) خلال الفترة 1 كانون الثاني - 31 كانون الاول لعام 2014. وقد تم اخذ عينات الدم من خلال وخز الكعب و تم فحص كل حديثي الولادة الذين تتراوح

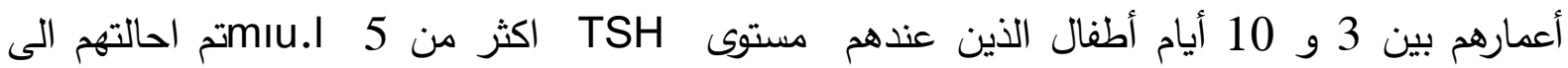
مستشفى الأطفال التعليمي للتاكيد تشخيص.

النتائج: من بين 13050 طفل تم فحصهم خلال هذه المدة 75\% (0.5) تم احالتهم ( TSH mlU/L قصور الغدة الدرقية الخلقي تم تشخيصها عند 11 (14.6) طفل , نسبة قصور الغدة الدرقية الخلقي في دراستنا كان 1 من 1186 طفل حي عند الولادة.

الاستنتاجات: ووفقا لهذه النتيجة التي خلصت إلى أن مدينة السليمانية لديهم نسبة عالية من قصور الغدة الدرقية الخلقي وفي المستقبل يجب فحص جميع الأطفال حديثي الولادة في هذه المنطقة بما في ذلك المناطق منطقة. 